\title{
A NOVEL AUTOMATED METHOD FOR THE IMPROVEMENT OF PHOTOGRAMIMETRIC DTM ACCURACY IN FORESTS
}

\section{NOVA AUTOMATSKA METODA ZA POBOLJŠANJE TOČNOSTI FOTOGRAMETRIJSKOG DTM-A U ŠUMAMA}

\author{
Mateo GAŠPAROVIĆ ${ }^{1}$ Anita SIMIC MILAS ${ }^{2}$, Ante SELETKOVIĆ ${ }^{3}$ Ivan BALENOVIĆ4*
}

\begin{abstract}
Summary
Accuracy of a Digital Terrain Model (DTM) in a complex forest environment is critical and yet challenging for accurate forest inventory and management, disaster risk analysis, and timber utilization. Reducing elevation errors in photogrammetric DTM $\left(\mathrm{DTM}_{\mathrm{PHM}}\right)$, which present the national standard in many countries worldwide, is critical, especially for forested areas. In this paper, a novel automated method to detect the errors and to improve the accuracy of DTM $\mathrm{PHM}_{\mathrm{PH}}$ for the lowland forest has been presented and evaluated. This study was conducted in the lowland pedunculate oak forest (Pokupsko Basin, Croatia). The DTM $_{\mathrm{PHM}}$ was created from three-dimensional (3D) vector data collected by aerial stereo-photogrammetry in combination with data collected from existing maps and field surveys. These data still present the national standard for DTM generation in many countries, including Croatia. By combining slope and tangential curvature values of raster DTM $_{\mathrm{PHM}}$, the proposed method developed in open source Grass GIS software automatically detected 91 outliers or $3.2 \%$ of the total number of source points within the study area. Comparison with a highly accurate LiDAR DTM confirmed the method efficiency. This was especially evident in two out of three observed subset areas where the root mean square error (RMSE) values decreased for $8 \%$ in one and $50 \%$ in another area after errors elimination. The method could be of great importance to other similar studies for forested areas in countries where the LiDAR data are not available.
\end{abstract}

KEY WORDS: digital terrain model (DTM), vertical accuracy, LiDAR, lowland forest

\section{INTRODUCTION}

\section{UVOD}

Accurate and reliable information of terrain surface, commonly represented using a Digital Terrain Model (DTM), is of a great importance to various environmental disciplines (Nelson et al., 2009). In forestry, DTMs are commonly used in forest inventory (Rahlf et al., 2015; Puliti et al., 2017, Balenović et al., 2017), in hydrological modelling (Furze et al., 2017), in disaster risk analysis (Ristić et al., 2017), and in various forestry operations including forest road netowork planning and design (Grigolato et al., 2017; Çalişkan and Karahalil, 2017a), timber utilization and harvesting (Çalişkan and Karahalil, 2017b; Đuka et al.,

\footnotetext{
1 Doc. dr. sc. Mateo Gašparović, University of Zagreb, Faculty of Geodesy, Chair of Photogrammetry and Sensing, Kačićeva 26, HR-10000 Zagreb, Croatia

${ }^{2}$ Anita Simic Milas, Bowling Green State University, School of Earth, Environment and Society, 190 Overman Hall, Bowling Green, OH 43403, USA

${ }^{3}$ Izv. prof. dr. Sc. Ante Seletković, Univeristy of Zagreb, Faculty of Forestry, Department of Forest Inventory and Management, Svetošimunska 25, HR-10002 Zagreb, Croatia

${ }^{4}$ Dr. sc. Ivan Balenović, Croatian Forest Research Institute, Division for Forest Management and Forestry Economics, Trnjanska cesta 35, HR-10000 Zagreb, Croatia, *ivanb@sumins.hr
} 
2017; Talbot et al., 2017), as well as environmental aspect of harvesting technologies (Cambi et al., 2018; Salmivaara et al., 2018).

However, accurate terrain modelling, either using terrestrial or remote sensing methods in the complex forest environment, is challenging as it often includes elevation errors that are hard to detect. Labour-intensive and time-consuming terrestrial surveys are difficult to obtain due to complex forest structure that often blocks satellite signals to Global Navigation Satellite Systems (GNSS) receivers or interrupts measurements with total stations. With the development of remote sensing technology, however, the collection of terrain information has become more practical and more feasible. The airborne Light Detection and Ranging (LiDAR) technology nowadays presents the most prominent and effective remote sensing method for DTM generation in complex forested areas (Gill et al., 2013; Stereńczak et al., 2016). Although many countries are capable of conducting nation-wide airborne LiDAR campaigns to produce DTMs, a comparatively large number of countries worldwide (e.g. European countries such as Croatia, Greece, Hungary, Slovakia, etc.) still rely on photogrammetrically-derived terrain data. In these countries, photogrammetrically-derived terrain data still present the national standard for DTMs (Höhle and Potuckova, 2011). However, only a limited number of studies have evaluated the accuracy of photogrammetrically derived DTM ( $\left.\mathrm{DTM}_{\mathrm{PHM}}\right)$ in forested areas either from aerial (Balenović et al., 2018; DeWitt et al., 2015; Gill et al., 2013) or satellite images (DeWitt et al., 2017; Hu et al., 2016). Studies confirmed a lower accuracy of $D_{\text {TM }} M_{\text {PHM }}$ when compared to LiDAR DTM (DTM $\left.{ }_{\mathrm{LiD}}\right)$, commonly observed through a certain number of outliers (i.e., gross errors). Balenović et al. (2018) conducted a comparative accuracy assessment of DTM $\mathrm{LiD}_{\mathrm{D}}$ and DTM $\mathrm{PHM}_{\mathrm{PH}}$ in dense lowland even-aged pedunculated oak forests in Croatia. The authors discovered that the nature of the national digital photogrammetric data (from which DTM was generated) considerably affected the DTM accuracy. After manual detection and elimination of the outliers from photogrammetric data, the accuracy of $\mathrm{DTM}_{\mathrm{PHM}}$ was notably improved. Unlike the studies related to the accuracy of DTM $\mathrm{PHM}_{\mathrm{P}}$, there are several studies related to DTM errors detection and accuracy improvements of free global DTMs (Tran et al., 2014) or DTMs derived from aerial (Schultz et al., 1999; López, 2002) and satellite data (Felicísimo et al., 2004).

To the best of the authors' knowledge, no previous studies have considered the automatization of error detection and improvements of $\mathrm{DTM}_{\mathrm{PHM}}$ in forested areas. The main aim of this study is to develop an automatic method for detection and elimination of elevation errors in photogrammetrically derived terrain data, and consequently to improve the vertical accuracy of DTM $\mathrm{PHM}_{\mathrm{PH}}$ for lowland pedunculated oak forests in Croatia. The idea is to develop a fast, simple and efficient method, which will be applicable for this and other similar forested areas worldwide. This paper presents the continuation of the previous research conducted by Balenović et al. (2018), which confirmed the improvements of DTM ${ }_{\mathrm{PHM}}$ accuracy after manual detection and elimination of the outliers.

\section{MATERIALS AND METHODS MATERIJAL I METODE}

\section{Study area - Područje istraživanja}

The study area is the management unit Jastrebarski lugovi, located in the Pokupsko Basin forest complex. The area covers 2,005.74 ha of the state-owned productive lowland forests, located in Central Croatia, approximately $35 \mathrm{~km}$ southwest of Zagreb (Figure 1). Even-aged pedunculate oak (Quercus robur L.) forests of different age classes ranging from 0 to 160 years are the main forest type and cover approximately $77 \%$ of the study area. The oak stands are commonly mixed with other tree species such as common hornbeam (Carpinus betulus L.), black alder (Alnus glutinosa (L.) Geartn.), and narrow-leaved ash (Fraxinus angustifolia Vahl.). The rest of the study area $(\approx 20 \%)$ is covered by even-aged narrow-leaved ash forests aged between 0 to 80 years. The ash stands are predominantly homogeneous and occasionally mixed with other tree species such as black

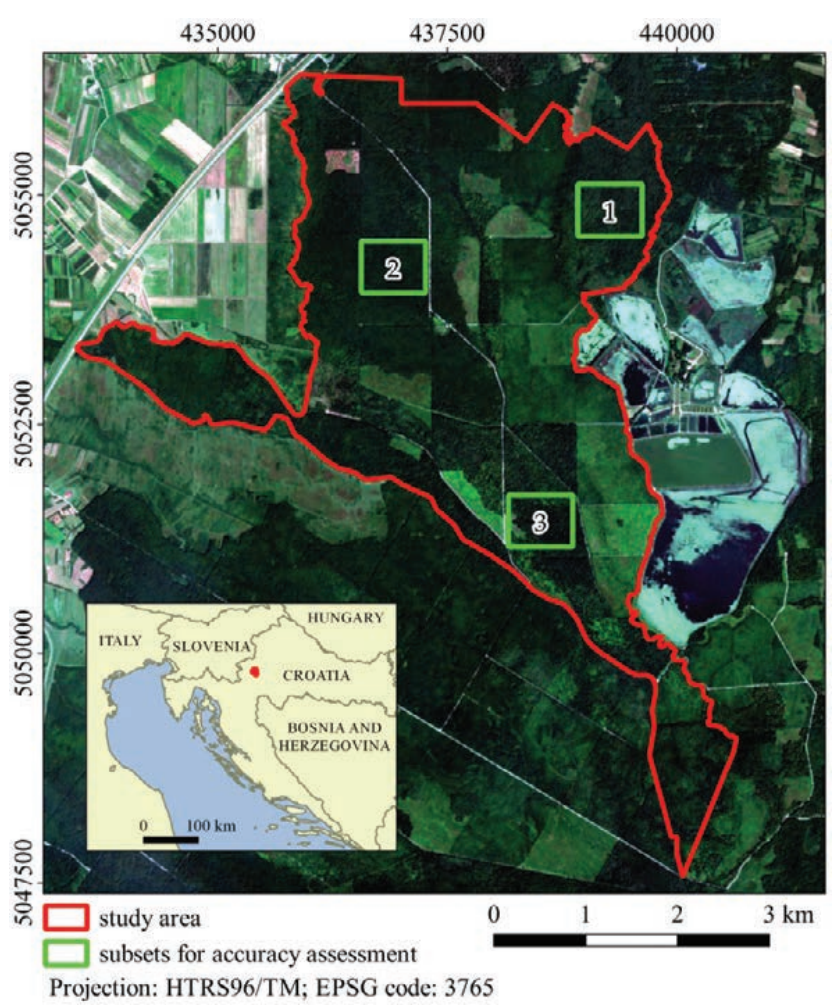

Figure 1 Study area (background: satellite image Sentinel 2A from 6 August 2016; Source: ESA, 2016).

Slika 1 Područje istraživanja (pozadina: satelitska snimka Sentinel $2 A$ od 6. kolovoza 2016.g.; Izvor: ESA, 2016). 


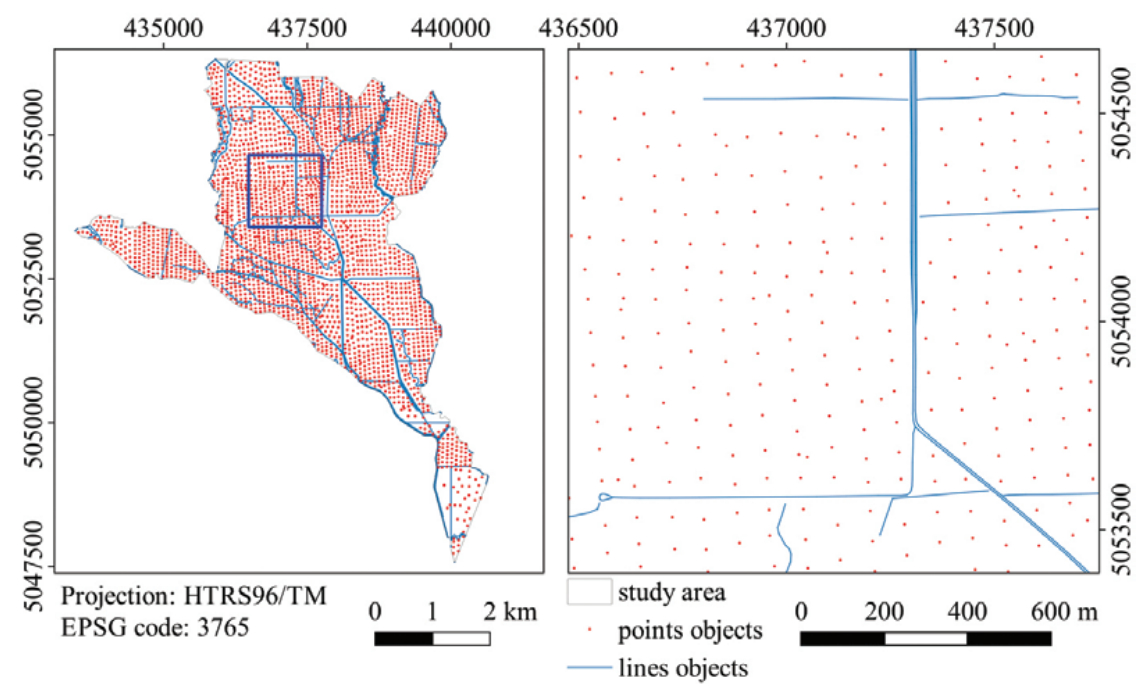

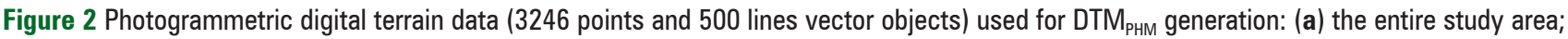
(b) subset for method demonstration bounded with blue rectangular on figure (a). For this study area, the average number of points in breaklines and formlines was 492 points $\cdot \mathrm{km}^{-2}$, while the average number of mass points and spot heights was 141 points $\mathrm{km}^{-2}$.

Slika 2. Fotogrametrijski digitalni podaci terena (3246 točkastih i 500 linijskih vektorskih objekata) korišteni za izradu DTM područje odabrano za demonstraciju metode, na slici (a) označeno plavim pravokutnikom. Na području istraživanja prosječni broj točaka u linijskim objektima iznosio je 492 točaka $\cdot \mathrm{km}^{-2}$, dok je prosječni broj točakastih objekata iznosio 141 točaka $\cdot \mathrm{km}^{-2}$.

alder and pedunculate oak. The understory species, such as common hazel (Corylus avellana L.) and common hawthorn (Crataegus monogyna Jacq.), are present in the entire area. The terrain is flat with ground elevations ranging from 105 to $121 \mathrm{~m}$ a.s.l. For more details on forest stands and site characteristics of the study area, please refer to the papers of Ostrogović Sever et al. (2017) and Balenović et al. (2018).

\section{Photogrammetric Digital Terrain Model (DTM Pнм $_{1}$ - Fotogrametrijski digitalni model reljefa (DTM ${ }_{\text {PHM }}$ )}

To create the $\mathrm{DTM}_{\mathrm{PHM}}$ for the study area, an official digital terrain data for the territory of Croatia were used. The data consisted of three-dimensional vector data including line data (breaklines, formlines) and point data (spot heights, mass points) (Figure 2). The data were primarily obtained from manual stereo photogrammetric methods using aerial images with the ground sampling distance of $\leq 30 \mathrm{~cm}$.

$\mathrm{DTM}_{\mathrm{PHM}}$ in the raster format with a spatial resolution of 0.5 $\mathrm{m}$ was generated from the national digital terrain data with the triangulated irregular network (TIN) and linear interpolation techniques using the Global Mapper software (ver. 19, Blue Marble Geographics, Hallowell, Maine, USA). A detailed description of each vector data type as well as of the vertical accuracy assessment of $\mathrm{DTM}_{\mathrm{PHM}}$ for the present study area can be found in Balenović et al. (2018)

\section{LiDAR Digital Terrain Model (DTM $\left.\mathrm{LiD}_{\mathrm{Li}}\right)$ -} LiDAR-ski digitalni model reljefa $\left(D_{T M} M_{\text {LiD }}\right)$

The $\mathrm{DTM}_{\mathrm{LiD}}$ was provided by the Hrvatske Vode Ltd. (Zagreb, Croatia) in the raster format with a spatial resolution of $0.5 \mathrm{~m}$. The LiDAR data were collected with an Optech ALTM Gemini 167 laser scanner under the leaf-on conditions in several surveys between 29 June and 25 August 2016. The resulting point densities considering 'all returns' and the 'last return' were 13.64 points. $\mathrm{m}^{-2}$ and 9.71

Table 1 Airborne LiDAR sensor and data characteristics.

Tablica 1. Karakteristike LiDAR senzora i prikupljenih podataka.

\begin{tabular}{|c|c|}
\hline Parameter - Parametar & $\begin{array}{l}\text { Specification } \\
\text { - Specifikacija }\end{array}$ \\
\hline Platform - Platforma & Pilatus P6 \\
\hline Sensor - Senzor & Optech ALTM Gemini 167 \\
\hline Flying date - Datum snimanja & 29.6.2016. - 25.8.2016. \\
\hline Flying height - Visina leta (m) & 720 \\
\hline Flying speed - Brzina leta $\left(\mathrm{m} \cdot \mathrm{s}^{-1}\right)$ & 51 \\
\hline $\begin{array}{l}\text { Pulse repetition frequency - Frekvencija } \\
\text { ponavljana pulsa (kHz) }\end{array}$ & 125 \\
\hline Scan frequency - Frekvencija skeniranja $(\mathrm{Hz})$ & 40 \\
\hline Field of view - Kut skeniranja $\left(^{\circ}\right)$ & \pm 25 \\
\hline Swath width - Širina skeniranja (m) & 671 \\
\hline $\begin{array}{l}\text { Max No of returns per pulse - Max broj } \\
\text { povrata po pulsu }\end{array}$ & 4 \\
\hline $\begin{array}{l}\text { Point density: all returns / last only - } \\
\text { Gustoća točaka: svi povrati / samo zadnji } \\
\text { povrat (points } \cdot \mathrm{m}^{-2}-\text { točaka } \cdot \mathrm{m}^{-2} \text { ) }\end{array}$ & $13.64 / 9.71$ \\
\hline $\begin{array}{l}\text { Horizontal / vertical accuracy - Horizontalna } \\
\text { / vertikalna točnost }(\mathrm{m})\end{array}$ & $0.15 / 0.08^{1}$ \\
\hline $\begin{array}{l}\text { Vertical accuracy - Vertikalna točnost: } \\
\text { RMSE / ME / SD (m) }\end{array}$ & $0.14 / 0.09 / 0.10^{2}$ \\
\hline
\end{tabular}

${ }^{1}$ According to data provider, accuracies were based on a considerably larger area (which included forested and non-forested areas) than the one considered in this study.

${ }^{2}$ According to study of Balenović et al. (2018): the vertical accuracy of a raster $\mathrm{DEM}_{\mathrm{LiD}}$ with a spatial resolution of $0.5 \mathrm{~m}$ was evaluated over the part of the present study area (991.50 ha) using 22 ground checkpoints. 
points. $\mathrm{m}^{-2}$, respectively. Characteristics of LiDAR sensor, data processing, and the accuracy of $\mathrm{DTM}_{\mathrm{LiD}}$ are presented in Table 1.

\section{Method for an automatic detection of elevation

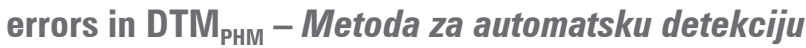 visinskih pogrešaka u DTM}

An automatic method for elevation errors detection in $\mathrm{DTM}_{\mathrm{PHM}}$ for the lowland forest was developed using Grass GIS software (Figure 3). The recent study of Balenović et al. (2018) revealed that the gross errors (outliers) in $\mathrm{DTM}_{\mathrm{PHM}}$ were caused by errors in the photogrammetric source data, primarily by the point data (mass and height points) used to generate $\mathrm{DTM}_{\mathrm{PHM}}$. Therefore, the presented method in this study focused exclusively on point data, while line data were not analyzed. Line objects representing embankment edges, forest roads, and river basins were excluded from the raster DTM $\mathrm{PHM}_{\mathrm{PH}}$ by creating a $25-\mathrm{m}$ buffer area around each feature, which is $50 \%$ less than the average distance of measured points for DTM. The slope analysis, performed on the raster $\mathrm{DTM}_{\mathrm{PHM}}$, distinguished areas with high slope inclination angles (S) that included both potential error points as well as error-free points of their neighborhood (Figure 4). To extract the error points from $\mathrm{DTM}_{\mathrm{PHM}}$, the method was complemented with the tangential curvature analysis (T) (Mitášová and Hofierka, 1993), where the tangential curvature represents the curvature orthogonal to the line of the steepest gradient (Alkhasawneh et al., 2013). The

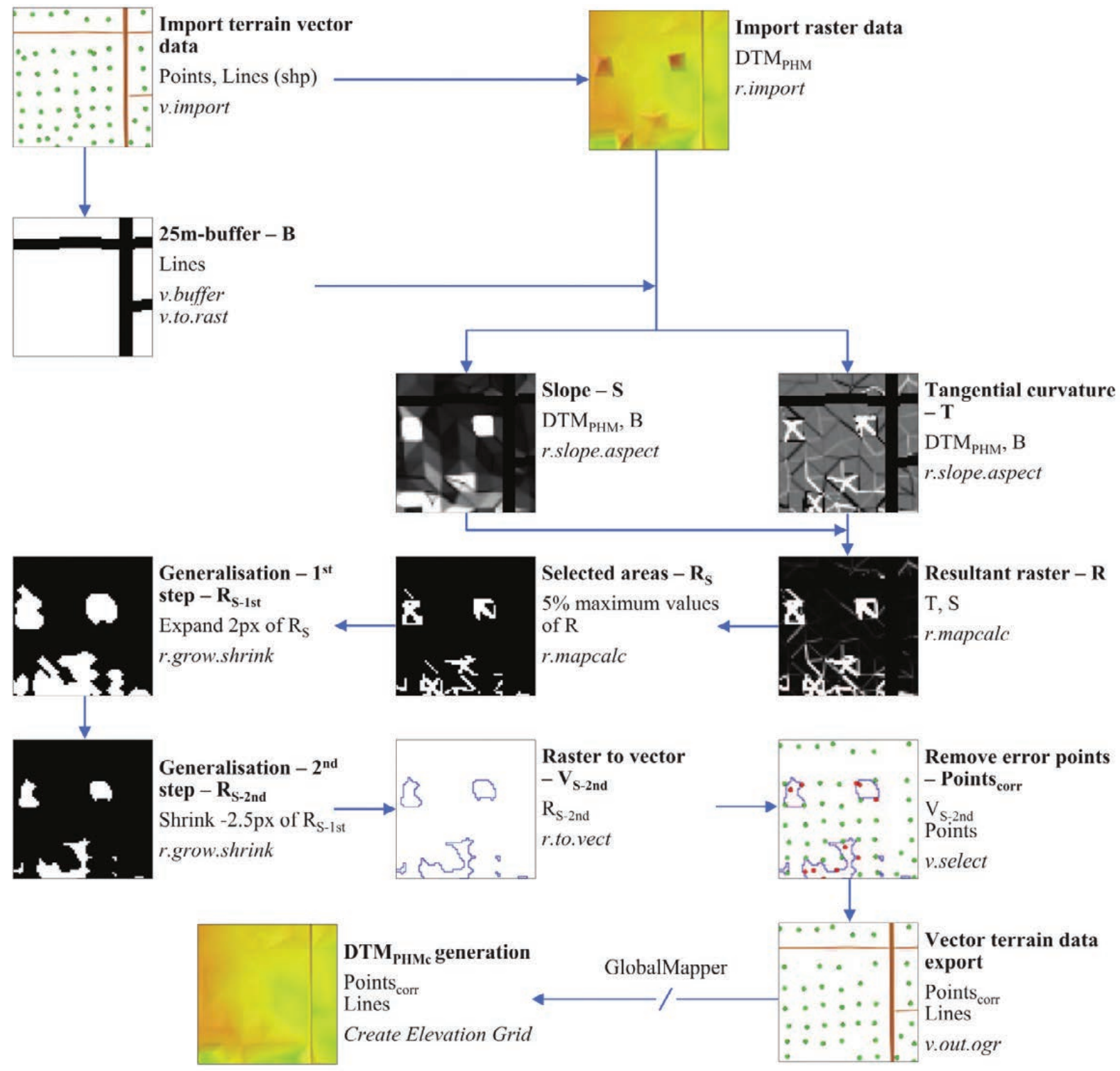

Explanation: Bold text - process stage title; Normal text - inputs for stage; Italic text - applied program function

Figure 3 The workflow of an automatic method for detection of elevation errors in DTM

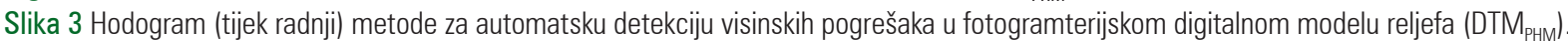




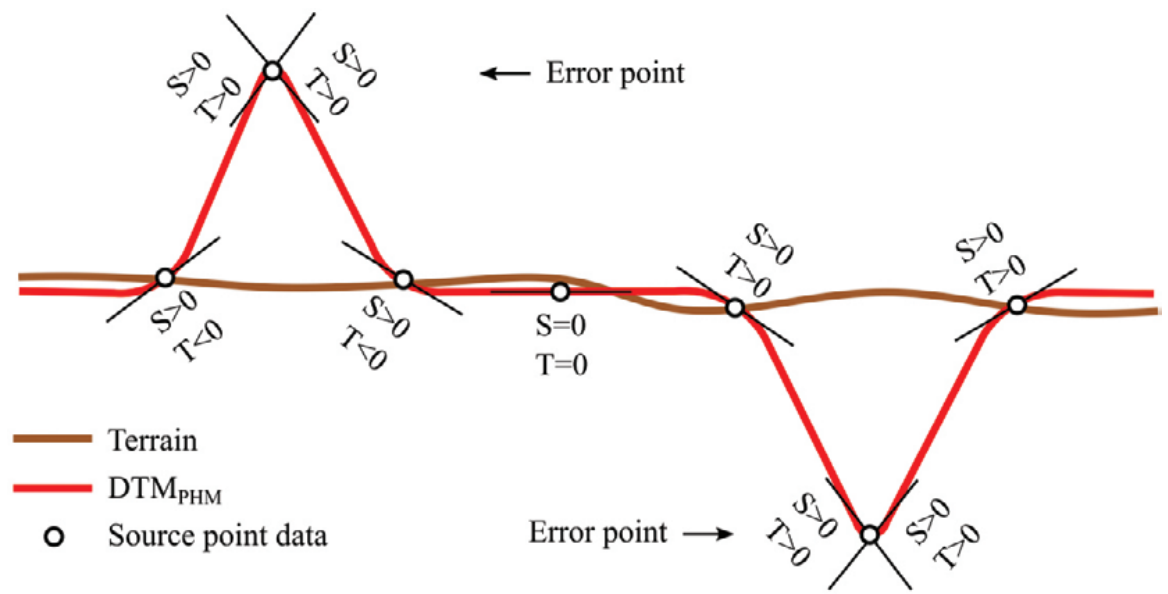

Figure 4 Variation of terrain slope and tangential curvature values.

Slika 4. Varijacija vrijednosti nagiba i tangencijalne zakrivljenosti terena.

output values of the analysis are always negative for concave DTM features and positive for convex DTM features (Figure 4) (Mitášová and Hofierka, 1993). When detecting error points, it does not matter if the points underestimate or overestimate the terrain, the absolute value $|\mathrm{T}|$ was used to create the resultant raster. Analogously to the slope analysis, if the areas with high $|\mathrm{T}|$ values $(|\mathrm{T}|>0)$ are in the nearest neighbourhood of a spot height or mass point, this may indicate a gross error at that point.

By combining the slope and tangential curvature using the expression: $\mathrm{R}=|\mathrm{T}| \cdot \mathrm{S}$, the resultant raster $(\mathrm{R})$ was calculated. From the resultant raster $(\mathrm{R})$ the potential error point areas were selected ( $5 \%$ maximal values of $\mathrm{R}$, according to Schultz et al., 1999) and extracted in a new binary raster $R_{S}$.

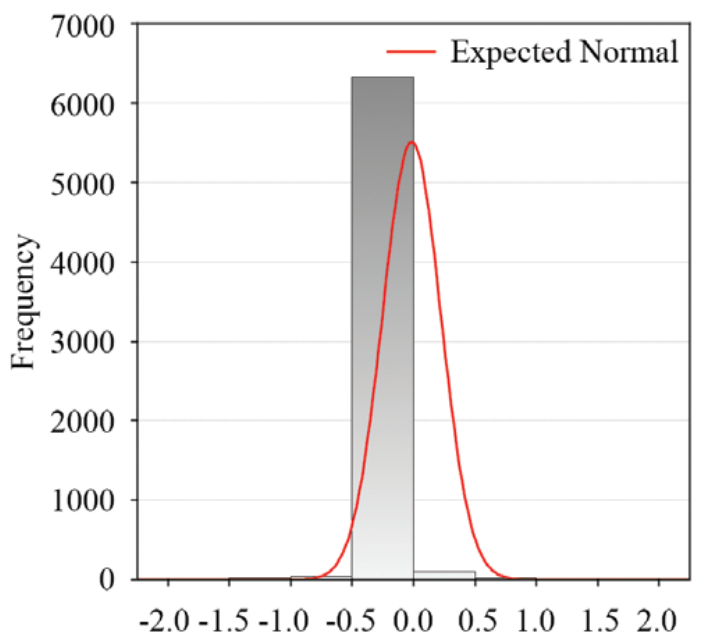

Vertical differences, $\Delta \mathrm{h}(\mathrm{m})$
To simplify the raster geometry of selected areas, the twostep generalisation process ( 2 pixel expansion followed by -2.5 pixel shrinking) of the $\mathrm{R}_{\mathrm{S}}$ was performed $\left(\mathrm{R}_{\mathrm{S}-2 \mathrm{nd}}\right)$ (Ablameyko and Pridmore, 2012). In the final step, the generalized $\mathrm{R}_{\mathrm{s}-2 \mathrm{nd}}$ raster was vectorized and overlapped with the point vector data of the original $\mathrm{DTM}_{\mathrm{PHM}}$. The error points were detected and removed from $\mathrm{DTM}_{\mathrm{PHM}}$ to produce the corrected point data DTM $\left(\mathrm{DTM}_{\mathrm{PHMc}}\right)$. The $\mathrm{DTM}_{\mathrm{PHMc}}$ and $\mathrm{DTM}_{\mathrm{PHM}}$ were generated in the Global Mapper software because the triangulation process is much faster than in Grass GIS.

\section{Accuracy assessment - Ocjena točnosti}

To evaluate the proposed method, a difference raster model between $\mathrm{DTM}_{\mathrm{PHM}}$ and $\mathrm{DTM}_{\mathrm{LiD}}$, as well as between $\mathrm{DTM}_{\mathrm{PHMc}}$

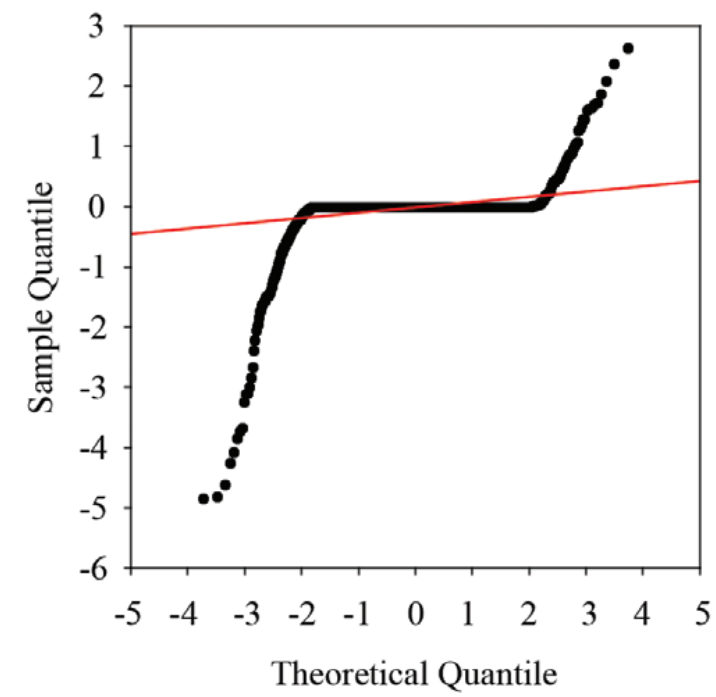

Figure 5 Normality test of differences between elevation values obtained from DTM ${ }_{\text {PHM }}$ and DTM ${ }_{\text {LD }}(\Delta h)$ : (a) histogram with a superimposed curve indicating normal distribution; (b) normal 0-0 plots. The normality test was based on the vertical differences obtained from 6560 points of a regular $50 \mathrm{~m}$ grid overlaid over the difference raster model (DTM PHM $_{\text {-DTM }}$ LiD).

Slika 5. Testiranje normalnosti između visinskih vrijednosti dobivenih iz $\operatorname{DTM}_{\text {PHM }}$ i $\operatorname{DTM}_{\text {Lі }}(\Delta h)$ : (a) histogram s istaknutom krivuljom normalne distribucije; (b) 0-0 grafovi. Testiranje normalnosti je bazirano na visinskim (vertiklanim) razlikama dobivenim iz 6560 točaka pravilne $50 \mathrm{~m}$-mreže točaka preklopljene preko raserskog modela razlika (DTM PHM $_{\text {-DTM }}$ LD $)$. 
Table 2 The vertical accuracy assessment of both DTM $\mathrm{PHM}_{\text {(original) and DTM }}$ (cHMc (corrected), with $\mathrm{DTM}_{\mathrm{LiD}}$ for the entire area (EA) and three subset areas (SA-1, SA-2, SA-3).

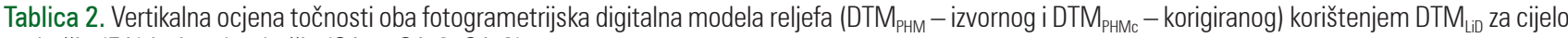
područje (EA) i tri podpodručja (SA-1, SA-2, SA-3).

\begin{tabular}{|c|c|c|c|c|c|c|c|c|c|c|c|c|}
\hline \multirow{2}{*}{$\begin{array}{c}\text { Area } \\
\text { Područje }\end{array}$} & \multirow{2}{*}{$\mathrm{N}_{\mathrm{pix}}$} & \multirow{2}{*}{$\begin{array}{c}\text { Difference } \\
\text { Model } \\
\text { Rasterski model } \\
\text { razlika }\end{array}$} & \multirow{2}{*}{$\mathrm{N}_{\mathrm{er}}$} & \multicolumn{5}{|c|}{$\begin{array}{l}\text { Standard accuracy measures } \\
\text { Standardne mjere točnosti }\end{array}$} & \multicolumn{4}{|c|}{$\begin{array}{l}\text { Robust accuracy measures } \\
\text { Robusne mjere točnosti }\end{array}$} \\
\hline & & & & $\min$ & $\begin{array}{l}\max \\
(\mathrm{m})\end{array}$ & $\begin{array}{l}\mathrm{ME} \\
(\mathrm{m})\end{array}$ & $\begin{array}{l}\mathrm{SD} \\
(\mathrm{m})\end{array}$ & $\begin{array}{l}\text { RMSE } \\
\text { (m) }\end{array}$ & $\begin{array}{l}\mathrm{O}_{50} \\
(\mathrm{~m})\end{array}$ & $\begin{array}{l}\text { NMAD } \\
(\mathrm{m})\end{array}$ & $\begin{array}{l}\mathrm{O}_{68.3} \\
(\mathrm{~m})\end{array}$ & $\begin{array}{r}\mathrm{Q}_{95} \\
(\mathrm{~m})\end{array}$ \\
\hline \multirow[t]{2}{*}{ EA } & $80,210,299$ & DTM $_{\text {PHM }}-$ DTM $_{\text {LiD }}$ & 91 & -5.38 & 7.60 & -0.19 & 0.53 & 0.56 & -0.16 & 0.47 & 0.05 & 0.56 \\
\hline & & DTM $_{\text {PHMC }}-$ DTM $_{\text {LiD }}$ & & -5.38 & 3.84 & -0.20 & 0.50 & 0.53 & -0.17 & 0.47 & 0.04 & 0.52 \\
\hline \multirow[t]{2}{*}{ SA-1 } & $1,418,541$ & DTM $_{\text {PHM }}-$ DTM $_{\text {LiD }}$ & 0 & -1.22 & 0.67 & -0.25 & 0.23 & 0.34 & -0.25 & 0.23 & -0.14 & 0.13 \\
\hline & & DTM $_{\text {PHMC }}-$ DTM $_{\text {LiD }}$ & & -1.22 & 0.67 & -0.25 & 0.23 & 0.34 & -0.25 & 0.23 & -0.14 & 0.13 \\
\hline \multirow[t]{2}{*}{ SA-2 } & $1,582,000$ & DTM $_{\text {PHM }}-$ DTM $_{\text {LiD }}$ & 11 & -2.74 & 4.93 & -0.24 & 0.78 & 0.81 & -0.04 & 0.41 & 0.12 & 0.60 \\
\hline & & DTM $_{\text {PHMc }}-$ DTM $_{\text {LiD }}$ & & -2.74 & 1.17 & -0.28 & 0.69 & 0.75 & -0.04 & 0.42 & 0.13 & 0.46 \\
\hline \multirow[t]{2}{*}{ SA-3 } & $1,580,336$ & DTM $_{\text {PHM }}-$ DTM $_{\text {LiD }}$ & 4 & -1.63 & 7.60 & -0.16 & 0.78 & 0.80 & -0.31 & 0.25 & -0.19 & 0.83 \\
\hline & & $\mathrm{DTM}_{\text {PHMc }}-\mathrm{DTM}_{\mathrm{LID}}$ & & -1.63 & 1.41 & -0.32 & 0.25 & 0.40 & -0.32 & 0.22 & -0.22 & 0.07 \\
\hline
\end{tabular}

$\mathrm{N}_{\mathrm{pix}}$ - number of pixels considered in statistical analyses / broj piksela uključen u statističku analizu; $\mathrm{N}_{\mathrm{er}}$ - number of detected and removed error points in original DTM${ }_{\text {PHM }}$ / broj detektiranih i uklonjenih pogrešaka (točaka) iz izvornog DTM ${ }_{\text {PHM }}$; min - maximum negative error / maksimalna negativna pogreška; max - maximum positive error / maksimalna pozitivna pogreška; ME - mean error / srednja pogreška; SD - standard deviation / standardna devijacija; RMSE - root mean square error / korijen srednje kvadratne pogreške; $\mathrm{O}_{50}-50 \%$ quantile / $50 \%$ kvantila; NMAD - normalized median absolute deviation / normaliziran medijan apsolutnih odstupanja; $\mathrm{O}_{68.3}$ - $68.3 \%$ quantile / $68.3 \%$ kvantila; $0_{95}$ - 95\% quantile / $95 \%$ kvantila

and $\mathrm{DTM}_{\mathrm{LiD}}$ with a spatial resolution of $0.5 \mathrm{~m}$ were created using the Global Mapper software.

The normality test of vertical errors distribution between $\mathrm{DTM}_{\mathrm{PHM}}$ and DTM $\mathrm{LiD}_{\text {b }}$ based on histograms and normal Q-Q plots revealed the non-normal distribution of vertical errors (Figure 5). Therefore, in addition to standard accuracy measures, robust accuracy measures, suggested by Höhle and Höhle (2009), were used for vertical accuracy assessment of

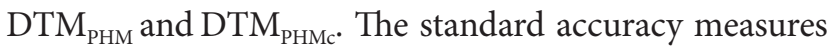
included the maximum positive error ( $\max$ ), maximum negative error ( $\mathrm{min}$ ), mean error (ME), standard deviation (SD) and root mean square error (RMSE), whereas the robust measures included the median or $50 \%$ quantile $\left(\mathrm{Q}_{50}\right)$, normalized median absolute deviation (NMAD), 68.3\% quantile $\left(Q_{68.3}\right)$ and 95\% quantile $\left(Q_{95}\right)$. The equations for all the measures can be found in Höhle and Höhle (2009).

To evaluate the method efficiency in more detail, the accuracy assessment was carried out for the entire study area, as well as for the three smaller rectangular subset areas (700 $\mathrm{m} \times 565 \mathrm{~m}$ ) (Figure 1). Values of all pixels from the difference raster within the entire area and three subset areas (with the exclusion of pixels within a 25-m buffer around line objects) were used to calculate accuracy measures. All statistical analyses were performed using the R programming language (ver. 3.3.3, R Core Team, Vienna, Austria).

\section{RESULTS WITH DISCUSSION} REZULTATI S DISKUSIJOM

For the entire study area, the method automatically detects 91 error points (outliers) or $3.2 \%$ of the total number of source points used to generate $\mathrm{DTM}_{\mathrm{PHM}}$ (Table 2). This means that, on average, one outlier occurs in the digital terrain source data within each 22.04 ha of the research area $(0.05$ outliers.ha $\left.{ }^{-1}\right)$. Using the previously described manual method, Balenović et al. (2018) detected a total of 21 outliers at the same but the somewhat smaller area (991.50 ha). This means that, on average, one outlier was detected within each 47.21 ha $\left(0.02\right.$ outliers $\left.\cdot h^{-1}\right)$. The greater number of outliers detected and eliminated by the automatic method leads to a considerably greater improvement of the $\mathrm{DTM}_{\mathrm{PHM}}$ vertical accuracy compared to the one obtained by the manual method, which is especially evident in subset areas 2 and 3 (Figure 1) according to several accuracy measures $\left(Q_{95}\right.$, max, SD, RMSE). Furthermore, the considerable decrease of $\mathrm{Q}_{95}$ and max values, as well as unchanged min values after removing the outliers indicate that only positive error points occur in $\mathrm{DTM}_{\mathrm{PHM}}$ when compared to reference $\mathrm{DTM}_{\mathrm{LiD}}$.

The improvements in accuracy are also evident in Figure 6 and Figure 7. Namely, Figure $6 \mathrm{a}-\mathrm{c}$ and Figure $7 \mathrm{a}, \mathrm{b}$ show no change because error points are not detected in subset area 1. Conversely, Figure $6 \mathrm{~d}$-e and Figure $6 \mathrm{~g}$-i, as well as Figure $7 \mathrm{c}-\mathrm{f}$ show the improvement in accuracy of DTM $\mathrm{PHMc}_{\mathrm{PH}} \mathrm{com}-$ pared to $\mathrm{DTM}_{\mathrm{PHM}}$ for subset areas 2 and 3. Detected points are very noticeable in the difference raster in Figure $6 \mathrm{~d}$ and Figure $6 \mathrm{~g}$ while the justification for their removal is confirmed by vertical profile through exemplary areas (Figure $6 f$ and Figure 6i). Furthermore, the elimination of outliers consequently leads to an improved coefficient of correlation (r) between $\mathrm{DTM}_{\mathrm{PHMc}}$ and $\mathrm{DTM}_{\mathrm{LiD}}$ elevation values compared to $r$ obtained between DTM $_{\mathrm{PHM}}$ and $\mathrm{DTM}_{\mathrm{LiD}}$ elevation values (Figure 7). 


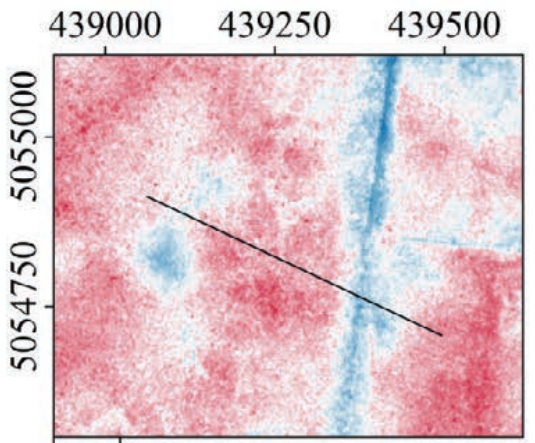

(a)
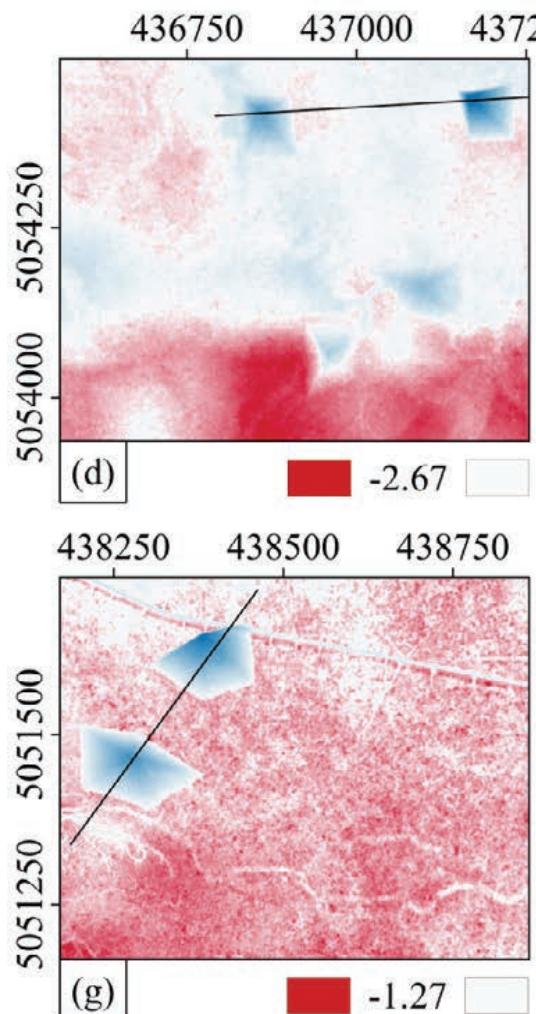

Projection: HTRS96/TM EPSG code: 3765

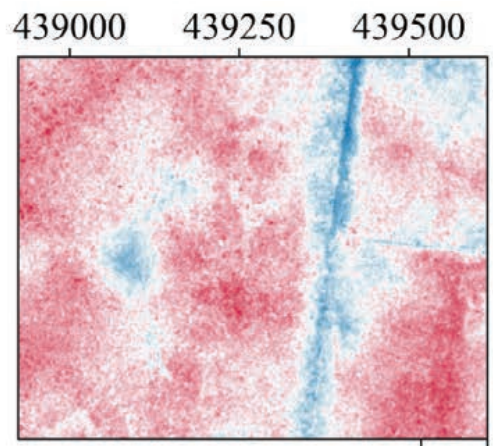

$0.00 \square 0.93 \mathrm{~m}$

(b)
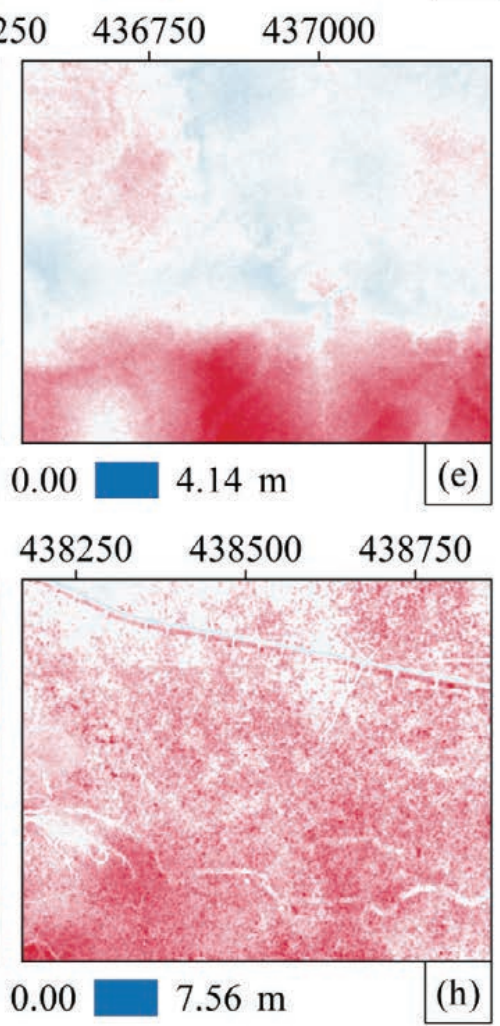

$0 \quad 100200300 \mathrm{~m}$
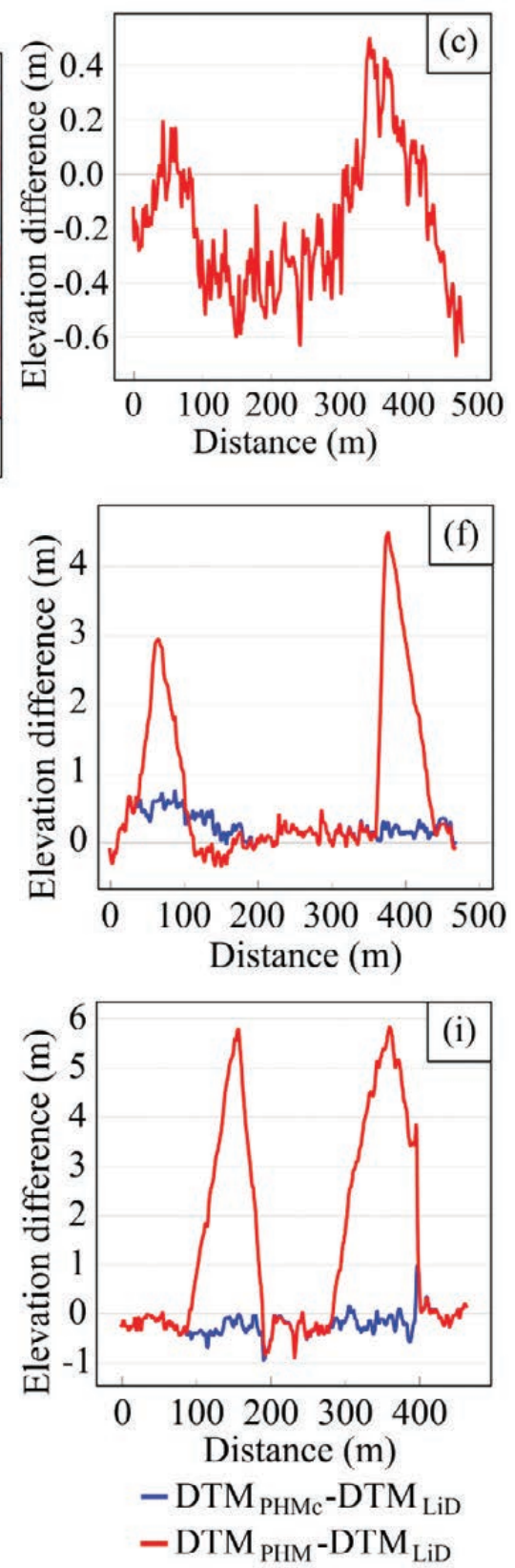

Figure 6 Left: Difference models DTM PHM $_{-}$DTM $_{\text {LiD }}$ for the part of the subset areas SA-1 (a), SA-2 (d), and SA-3 (g); Mid: Difference models DTM${ }_{\text {PHMc }}$-DTM $_{\text {LiD }}$ for SA-1 (b), SA-2 (e), and SA-3 (h); Right: Vertical profile throughout the exemplary area marked with black line on difference models.

Slika 6. Lijevo: Rasterski model razlike DTM РHM $_{\text {-DTM }}$ za dijelove podpodručja SA-1 (a), SA-2 (d), i SA-3 (g); Sredina: Rasterski model razlike DTMPHMcDTMLiD for SA-1 (b), SA-2 (e), i SA-3 (h); Desno: Vertikalni profil kroz odabrana područja označena crnom linijom na rasterskim modelima razlika.

Direct comparison with other similar studies (Felicísimo et al., 2004; López, 2002; Schultz et al., 1999; Tran et al., 2014) is hindered due to a number of differences between input data, DTMs resolutions, land cover type, and validation data. Yet, the methods presented in the previous studies improved the DTM accuracy, i.e. decreased the RMSE for $2 \%$ (Felicísimo et al., 2004), >2\% (López, 2002), 21\% (Tran et al., 2014), and 27\% (Schultz et al., 1999). This study suggests an accuracy improvement as the RMSE values decreased by $8 \%$ and $50 \%$ in the two subset areas for which the vali- dation was conducted. Considering the fact that, unlike our study, neither of the mentioned studies was dealing with the improvement of DTM accuracy in forested areas, the obtained results of this research add to the significance of the research. Moreover, to the best of our knowledge, this is the first study that proposes the automatic method for the vertical accuracy improvement of the $\mathrm{DTM}_{\mathrm{PHM}}$ in forests.

Knowing the structure and characteristics of photogrammetrically derived DTMs (e.g. low density of points, lower accuracy) in forested areas of Croatia, one should keep in 

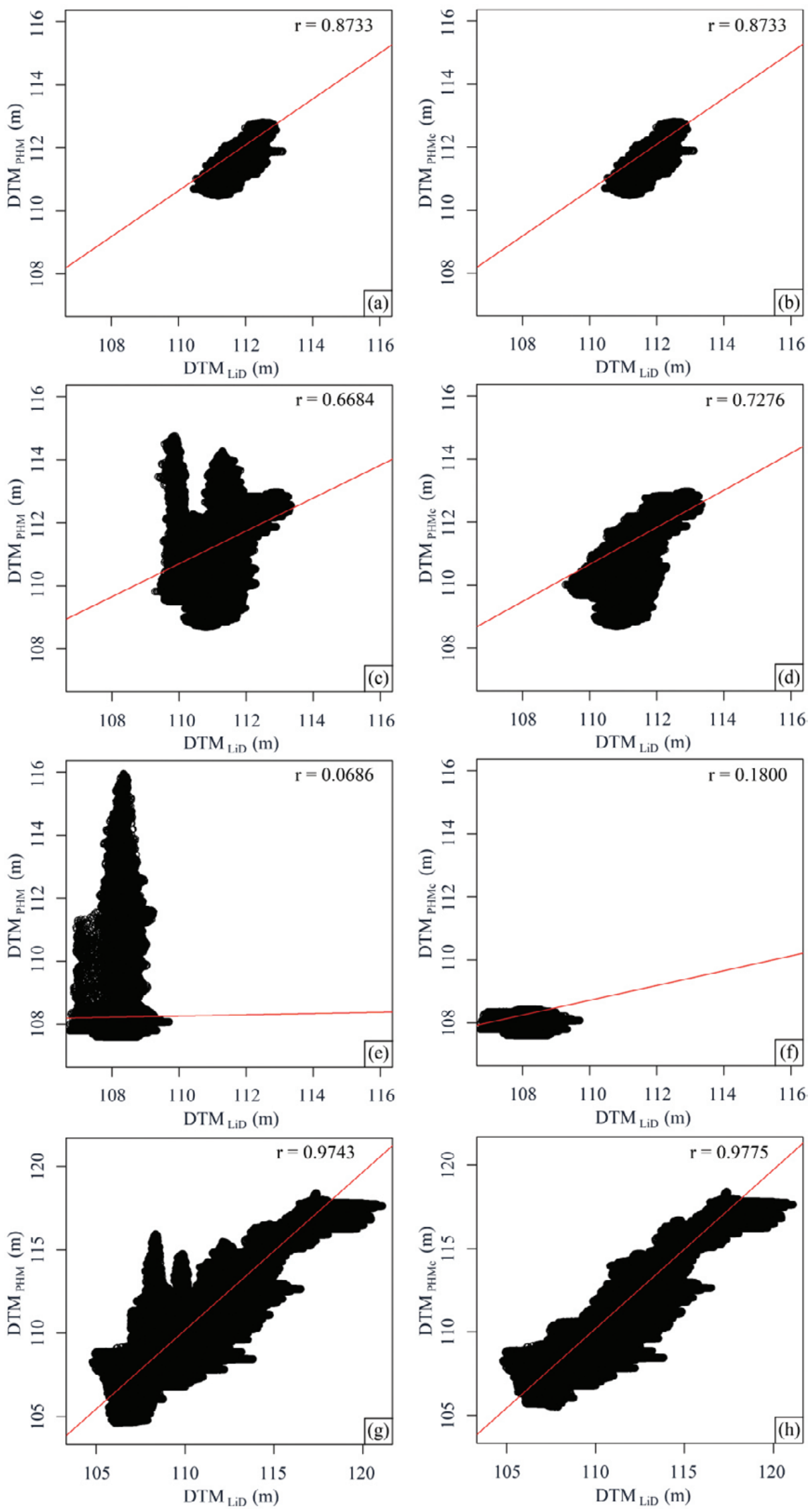

Figure 7 DTM $_{\text {Рнм }}$ and DTM Рнмс $_{\text {c elevations in comparison with DTM }}$ LiD elevations for: (a), (b) subset area 1; (c), (d) subset area 2; (e), (f) subset area 3; (g), (h) entire study area.

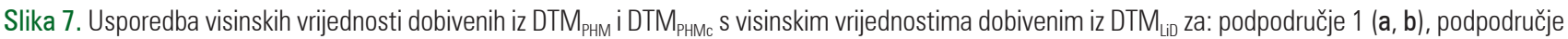
2 (c, d), podpodručje $3(e, f)$ i čitavo područje istraživanja $(g, h)$. 
mind that the applicability of this method is limited to mostly flat terrains. In other words, the method might not perform well for mountainous areas characterized by steep terrain; not because of the method inefficiency but rather due to a very low density of photogrammetric data in such forested areas. However, the method is expected to be highly applicable to forests with mostly flat terrain (slopes $<10^{\circ}$ ), similar to those that occupy $\approx 27 \%$ of a total forest area in Croatia (Ministry of Agriculture, 2016).

\section{CONCLUSIONS ZAKLJUČCI}

This research presented a novel automated method for detection and removal of elevation errors in a photogrammetric DTM for forest areas characterized by flat terrain. By combining slope and tangential curvature values of raster DTM in the open source Grass GIS software, the method automatically detected and removed the elevation errors in a practical, fast and costless fashion. The comparison with the highly accurate LiDAR DTM confirmed that the presented method successfully detected and eliminated the elevation errors from photogrammetrically derived DTM in a dense lowland forest, and consequently greatly improved its vertical accuracy. Although the application of the method is limited to mostly flat terrain, the findings of this research could be of immense importance to other studies that consider similar forested areas particularly in the countries where the highly accurate LiDAR DTM are still unavailable.

\section{ACKNOWLEDGMENTS ZAHVALA}

This research has been fully supported by the Croatian Science Foundation under the project IP-2016-06-7686 "Retrieval of Information from Different Optical 3D Remote Sensing Sources for Use in Forest Inventory (3D-FORINVENT)". The authors wish to thank the company Hrvatske vode, Zagreb, Croatia, for providing LiDAR data.

\section{REFERENCES}

\section{LITERATURA}

- Ablameyko, S., T. Pridmore, 2012: Machine Interpretation of Line Drawing Images: Technical Drawings, Maps and Diagrams. Springer-Verlag, London.

- Alkhasawneh, M.S., U.K. Ngah, L.T. Tay, N.A. Mat Isa, M.S. AlBatah, 2013: Determination of Important Topographic Factors for Landslide Mapping Analysis Using MLP Network. Sci. World J., 415023.

- Balenović, I., A. Šimić Milas, H. Marjanović, 2017: A Comparison of Stand-Level Volume Estimates from Image-Based Can- opy Height Models of Different Spatial Resolutions. Remote Sens., 9 (3): 205.

- Balenović, I., M. Gašparović, A. Šimić Milas, A. Berta, A. Seletković, 2018: Accuracy assessment of digital terrain models of lowland pedunculate oak forests derived from airborne laser scanning and photogrammetry. Croat. J. For. Eng., 39 (1): $117-$ 128.

- Calişkan, E., 2017a: Planning Of Environmentally Sound Forest Road Route Using GIS \& S-MCDM. Šum. list, 141 (11-12): 583-591.

- Çalişkan, E., U. Karahalil, 2017b: Evaluation of Forest Road Network and Determining Timber Extraction System Using GIS: A Case Study in Anbardağ Planning Unit. Šum. list, 141 (3-4): 163-171.

- Cambi, M., F. Giannetti, F. Bottalico, D. Travaglini, T. Nordfjell, G. Chirici, E. Marchi, 2018: Estimating machine impact on strip roads via close-range photogrammetry and soil parameters: a case study in central Italy. iForest, 11: 148-154.

- DeWitt, J.D., T.A. Warner, P.G. Chirico, S.E. Bergstresser, 2017: Creating high-resolution bare-earth digital elevation models (DEMs) from stereo imagery in an area of densely vegetated deciduous forest using combinations of procedures designed for lidar point cloud filtering. GISci Remote Sens., 54 (4): 552572.

- DeWitt, J.D., T.A. Warner, J.F. Conley, 2015: Comparison of DEMS derived from USGS DLG, SRTM, a statewide photogrammetry program, ASTER GDEM and LiDAR: implications for change detection. GISci. Remote Sens., 52 (2): 179-197.

- Đuka, A., S. Grigolato, I. Papa, T. Pentek, T. Poršinsky, 2017: Assessment of timber extraction distance and skid road network in steep karst terrain. iForest, 10: 886-894.

- Felicísimo, A.M., A. Cuartero, F.J. Ariza, 2004: A method for the improvement elevation data generated from automated photogrammetric methods into SIS. Int. Arch. Photogramm., 35: 255260.

- Furze, S., J. Ogilvie, P.A. Arp, 2017: Fusing Digital Elevation Models to Improve Hydrological Interpretations. J. of Geogr. Inf. Syst., 9 (5): 558-575.

- Gil, A.L., L. Núñez-Casillas, M. Isenburg, A.A. Benito, J.J.R. Bello, M. Arbelo, 2013: A comparison between LiDAR and photogrammetry digital terrain models in a forest area on Tenerife Island. Can. J. Remote Sen., 39 (5): 396-409.

- Grigolato, S., O. Mologni, R. Cavalli, 2017: GIS Applications in Forest Operations and Road Network Planning: an Overview over the Last Two Decades. Croat. J. For. Eng., 38 (2): 175-186.

- Höhle, J., M. Höhle, 2009: Accuracy assessment of digital elevation models by means of robust statistical methods. ISPRS J. Photogramm., 64 (4): 398-406.

- Höhle, J., M. Potuckova, 2011: Assessment of the quality of digital terrain models, European Spatial Data Research, Frankfurt, Report No. 60, p. 91. http://www.eurosdr.net/sites/default/files/ uploaded_files/60_0.pdf (accessed 15 December 2017).

- Hu, F., X.M. Gao, G.Y. Li, M. Li, 2016: DEM extraction from WorldView-3 stereo-images and accuracy evaluation. Int. Arch. Photogramm., 41: 327-332.

- López, C., 2002: An experiment on the elevation accuracy improvement of photogrammetrically derived DEM. Int. J. Geogr. Inf. Sci., 16 (4): 361-375. 
- Ministry of Agriculture, 2016: Forest Management Area Plan for the Republic of Croatia (2016-2025). URL: http://www.mps. $\mathrm{hr} / \mathrm{hr} /$ sume/sumarstvo/sumskogospodarska-osnova-2016-2025 (accessed 28 March 2018).

- Mitášová, H., J. Hofierka, 1993: Interpolation by regularized spline with tension: II. Application to terrain modeling and surface geometry analysis. Math. Geol., 25 (6): 657-669.

- Nelson, A., H.I. Reuter, P. Gessler, 2009: DEM production methods and sources. Dev. Soil Sci., 33: 65-85.

- Ostrogović Sever, M.Z., E. Paladinić, Z. Barcza, D. Hidy, A. Kern, M. Anić, H. Marjanović, 2017: Biogeochemical Modelling vs. Tree-Ring Measurements - Comparison of Growth Dynamic Estimates at Two Distinct Oak Forests in Croatia. South-East Eur. For., 8 (2): 71-84.

- Puliti, S., L. Theodor, E.T. Gobakken, E. Næsset, 2017: Use of partial-coverage UAV data in sampling for large scale forest inventories. Remote Sens. Environ., 194: 115-126.

- Rahlf, J., J. Breidenbach, S. Solberg, R. Astrup, 2015: Forest Parameter Prediction Using an Image-Based Point Cloud: A Comparison of Semi-ITC with ABA. Forests, 6 (11): 4059-4071.

- Ristić, R., S. Polovina, I. Malušević, B. Radić, V. Milčanović, M. Ristić, 2017: Disaster Risk Reduction Based on a GIS Case Study of the Čađavica River Watershed. South-East Eur. For., 8 (2): 99-106.

- Salmivaara, A., M. Miettinen, L. Finér, S. Launiainen, H. Korpunen, S. Tuominen, J. Heikkonen, P. Nevalainen, M. Sirén, J. Ala-Ilomäki, J. Uusitalo, 2018: Wheel rut measurements by forest machine-mounted LiDAR sensors - accuracy and potential for operational applications? Int. J. For. Eng., 29 (1): 41-52.

- Schultz, H., E.M. Riseman, F.R. Stolle, D.M. Woo, 1999: Error detection and DEM fusion using self-consistency. In: Proceedings of the Seventh IEEE International Conference on Computer Vision, Kerkyra, Greece, Vol. 2: 1174-1181.

- Stereńczak, K., M. Ciesielski, R. Balazy, T. Zawiła-Niedźwiecki, 2016: Comparison of various algorithms for DTM interpolation from LIDAR data in dense mountain forests. Eur. J. Remote Sens., 49 (1): 599-621.

- Talbot, B., M. Pierzchała, R. Astrup, 2017: Applications of Remote and Proximal Sensing for Improved Precision in Forest Operations. Croat. J. For. Eng., 38 (2): 327-336.

- Tran, T.A., V. Raghavan, S. Masumoto, P. Vinayaraj, G. Yonezawa, 2014: A geomorphology-based approach for digital elevation model fusion-Case study in Danang City, Vietnam. Earth Surf. Dynam., 2: 403-417.

\section{SAŽETAK}

Digitalni model reljefa (DTM, engl. Digital Terrain Model) ima široku i važnu primjenu u mnogim djelatnostima, uključujući i šumarstvo. Međutim, precizno modeliranje terena, odnosno izrada DTM-a u šumama, bilo korištenjem terenskih metoda ili metoda daljinskih istraživanja, izazovan je i vrlo zahtjevan zadatak. U većini razvijenih zemalja svijeta, zračno lasersko skeniranje (ALS, engl. Airborne Laser Scanning) bazirano na LiDAR (engl. Light Detection and Ranging) tehnologiji trenutno predstavlja glavnu metodu za izradu DTM-a. Uslijed mogućnosti laserskog zračenja da penetrira kroz krošnje drveća, LiDAR tehnologija se pokazala kao efektivna i brza metoda za izradu DTM-a u šumskim područjima s vrlo velikom točnošću. Međutim, u mnogim zemljama svijeta, uključujući i Hrvatsku, zračno lasersko skeniranje nije u potpunosti provedeno, tj. samo su manji dijelovi zemlje pokriveni s podacima zračnog laserskog skeniranja. U tim slučajevima, DTM temeljen na stereo-fotogrametrijskoj izmjeri aerosnimaka potpomognut s terenskim podacima najčešće predstavlja glavni izvor informacija za izradu DTM-a. Poznato je da tako izrađen DTM u šumskim predjelima ima manju točnost od DTMa dobivenog na temelju zračnog laserskog skeniranja zbog pokrivenosti terena vegetacijom. Također, u okviru nedavno provedenog istraživanja (Balenović i dr., 2018) utvrđeno je da takvi službeni fotogrametrijski digitalni podaci terena u šumskim predjelima sadrže određen broj tzv. grubih grešaka, koje mogu značajno utjecati na točnost izrađenog DTM-a. Nakon vizualnog detektiranja i manualnog uklanjanja tih pogrešaka, Balenović i dr. (2018) utvrdili su značajno poboljšanje točnosti fotogrametrijskog DTM-a.

Stoga je glavni cilj ovoga rada razviti automatsku metodu za detekciju i eliminaciju vertikalnih pogrešaka $u$ fotogrametrijskim digitalnim podacima terena te na taj način poboljšati točnost fotogrametrijskog DTM-a u nizinskim šumskim područjima Hrvatske. Ideja je razviti brzu, jednostavnu i učinkovitu metodu koja će biti primjenjiva i za druga šumska područja sličnih karakteristika, a za koja ne postoje DTM dobiven zračnim laserskim skeniranjem.

Istraživanje je provedeno u nizinskim šumama na području gospodarske jedinice Jastrebarski lugovi, u neposrednoj blizini Jastrebarskog (Slika 1). Istraživanjem je obuhvaćena površina od 2.005,74 ha, na kojoj su u najvećoj mjeri zastupljene jednodobne sastojine hrasta lužnjaka (Quercus robur L.), a u manjoj mjeri jednodobne sastojine poljskog jasena (Fraxinus angustifolia L.) te jednodobne sastojine običnoga graba (Carpinus betulus L.). Nadmorska visina područja istraživanja kreće se u rasponu od 105 do $121 \mathrm{~m}$. 
Fotogrametrijski DTM $\left(\mathrm{DTM}_{\mathrm{PHM}}\right)$ je izrađen iz digitalnih vektorskih podataka terena (prijelomnice, linije oblika, markantne točke terena i pravokutne mreže visinskih točaka) nabavljenih iz Državne geodetske uprave (Slika 2). Ti podaci predstavljaju nacionalni standard i jedini su dostupni podaci za izradu DTM-a u Hrvatskoj. Detaljan opis vektorskih podataka dan je u radu Balenović i dr. (2018). Prvo je iz digitalnih terenskih podataka izrađena nepravilna mreža trokuta, koja je potom linearnom interpolacijom pretvorena u rasterski $\mathrm{DTM}_{\mathrm{PHM}}$ prostorne rezolucije (veličine piksela) 0,5 m. Automatska metoda za detekciju i eliminaciju vertikalnih pogrešaka fotogrametrijskog DTM-a u nizinskim šumskim područjima razvijena je u slobodnom programskom paketu Grass GIS (Slika 3). Kombinacijom vrijednosti nagiba i tangencijalne zakrivljenosti terena rasterskog $\mathrm{DTM}_{\mathrm{PHM}}$ (Slika 4), automatskom metodom su detektirane 91 grube greške (engl. outliers). Drugim riječima, utvrđeno je da 91 točkasti vektorski objekt pogrešno prikazuje stvarnu visinu terena. Navedeni broj čini 3,2 \% od ukupnog broja točkastih objekata korištenih za izradu $\mathrm{DTM}_{\mathrm{PHM}}$-a. Nakon eliminacije detektiranih pogrešaka izrađen je novi, korigirani fotogrametrijski DTM $\left(\right.$ DTM $\left._{\text {PHMc }}\right)$.

Za ocjenu vertikalne točnosti izvornog $\left(\mathrm{DTM}_{\mathrm{PHM}}\right)$ i korigiranog DTM-a $\left(\mathrm{DTM}_{\mathrm{PHMc}}\right)$ korišten je visoko precizni DTM dobiven zračnim laserskim skeniranjem $\left(\mathrm{DTM}_{\mathrm{LiD}}\right)$. U tu svrhu su izrađeni rasteri razlika između $\mathrm{DTM}_{\mathrm{PHM}}$ i $\mathrm{DTM}_{\mathrm{LiD}}$, te između $\mathrm{DTM}_{\mathrm{PHMc}}$ i $\mathrm{DTM}_{\mathrm{LiD}}$. Kako je preliminarnom analizom utvrđeno da vertikalne razlike između $\mathrm{DTM}_{\mathrm{PHM}} \mathrm{i} \mathrm{DTM}_{\mathrm{LiD}}$ nisu normalno distribuirane (Slika 5), za ocjenu točnosti su uz normalne mjere točnosti korištene i tzv. robusne mjere točnosti (Tablica 2). Dobiveni rezultati ukazuju na poboljšanje vertikalne točnosti fotogrametrijskog DTM-a primjenom razvijene automatske metode. To je posebice uočljivo na podpodručjima 2 i 3 (Slika 6 i 7 ) u kojima se nakon uklanjanja detektiranih grešaka, korijen srednje kvadratne pogreške (RMSE, engl. root mean square error) smanjio za $8 \%$ odnosno $50 \%$ (Tablica 2).

$\mathrm{Na}$ temelju dobivenih rezultata i usporedbe $s \mathrm{DTM}_{\mathrm{LiD}}$, može se zaključiti da predložena metoda uspješno detektira i eliminira vertikalne pogreške fotogrametrijskog DTM-a u nizinskim šumskim područjima, te slijedom toga poboljšava njegovu vertikalnu točnost.

KLJUČNE RIJEČI: digitalni model reljefa (DTM), vertikalna točnost, LiDAR, nizinska šumska područja 